\title{
Prevalência de babesia e anaplasma bovina na região do Alto Uruguai gaúcho
}

Camila Giaretton, Camile Luize Pozzebon, Diane Maria Zarpellon, Denison Kossmann Meneses, Ticiany Maria Dias Ribeiro, Álvaro Luis Ranghetti, Ângela Faccin, Franciele de Oliveira, Thiago de Souza Rosés, Daniela dos Santos de Oliveira

Instituto de Desenvolvimento Educacional do Alto Uruguai (IDEAU), Getúlio Vargas, RS, Brasil

*Autor correspondente

e-mail: veterinaria.gv@ideau.com.br

\section{Resumo}

A tristeza parasitária bovina é um complexo de doenças causadas por infecções com Babesia e Anaplasma, transmitidas por carrapatos (Boophilus microplus) e moscas hematófagas (Stomoxys calcitrans, tabanídeos, culicídeos), respectivamente, constituindo-se fator limitante ao desenvolvimento da pecuária nos países tropicais e subtropicais. Objetivou-se analisar a presença da rickettsia Anaplasma marginale e dos protozoários Babesia bovis e B. bigemina em 61 animais de quatro propriedades do município de Paulo Bento/RS. A seleção dos animais para coleta teve como base os sinais clínicos. Posteriormente, coletou-se amostras de sangue da veia coccígea, as quais foram levadas para o laboratório de Microscopia da Faculdade IDEAU de Getúlio Vargas/RS, para a realização de esfregaço sanguíneo e coloração com Kit Panótico Rápido. Após o preparo, as lâminas foram observadas ao microscópio óptico, onde se encontrou provável presença de protozoários e rickettsia parasitando eritrócitos. 50\% dos animais apresentaram sinais clínicos e presença de parasitas intraeritrocitários. A B. bovis se apresenta em forma de um pequeno anel ou de pêra (1,0 a 2,5 micrômetros); em casos positivos, os capilares apresentam-se repletos de eritrócitos parasitados por B. bovis, e nos negativos é visualizando apenas as hemácias. A B. bigemina é mais pleomorfa, sendo encontrados trofozoítos em forma de anel (2,5 a 4,0 micrômetros), em forma amebóide (no processo de divisão) e piriforme (no final da divisão). 0 A. marginale, como as demais rickettsias, apresenta-se como uma pequena esfera de cor violeta escura ou preta, localizada na margem interna dos eritrócitos. Os resultados encontrados deram-se ao fato da grande maioria dos animais apresentarem infestações de carrapatos, pois as propriedades em que foram realizadas as coletas tiveram prevalência de carrapato ou ainda enfrentavam altos índices de parasitismo no rebanho, por ser no período de clima favorável para a reprodução do mesmo, com a ocorrência de casos de babesiose e até de perda de animais. Todas as propriedades realizavam tratamento preventivo com sal mineral homeopático e outros métodos de controle do vetor; mesmo assim, 
estes não apresentaram resultados eficazes de controle até o momento, pois é necessário que seja feito um tratamento de 12 - 36 meses para que ocorra a eliminação por completo do ciclo. Em relação aos demais carrapaticidas usados, estava ocorrendo resistência pelo fato de os produtores não terem um controle estabelecido de aplicações e vida útil dos mesmos, surgindo cepas resistentes. A maior prevalência ocorreu numa das propriedades onde era realizada com frequência compra e venda de animais, quando comparada às demais propriedades onde não há intensa movimentação do rebanho, tendo em vista que os animais recém-introduzidos em uma região endêmica são suceptíveis à enfermidade. Conhecendo o histórico clínico das propriedades e os sinais apresentados pelos animais, chega-se ao diagnóstico. 